Business and Economics Research Journal

Volume 7 Number 32016

pp. $137-154$

ISSN: $1309-2448$

DOI Number: 10.20409/berj.2016321813

\title{
Nostaljiye Genç Bakış: Nostalji İçerikli Reklamların Postmodern Bireyler Üzerindeki Etkisi
}

\author{
Ebru Güzel ${ }^{\mathrm{a}}$ \\ Elif Yolbulan Okan ${ }^{\mathrm{b}}$
}

Öz: Her alanda rekabetin yoğunlaşması ve tüketici beklentilerinin her geçen gün artması firmaların markalaşma stratejilerinde sürekli yeni arayışlara başvurmasını gerektirmektedir. Markalar tüketicilerinin dikkatini çekecek, onların hem düşüncelerine, hem duygularına hitap edecek yeni unsurlar ararken nostalji ve retro kavramının önemli fırsatlar sunduğu görülmektedir. Reklamlarda nostalji temasının kullanımının giderek artması etkinlik konusunda araştırmaların gerekliliğini ortaya çıkarmıştır. Bu araştırmanın amacı özellikle postmodern bireyler olarak tanımlanan 1980-1985 arası doğumlu kohort örnneklem grubunun nostalji eğilimlerini belirlemek ve reklamlarda kullanılan nostalji temasına yaklaşımlarını analiz etmektir. Anket yöntemiyle toplanan veriler analiz edildiğinde katılımcıların nostalji eğilimleri tespit edilmiş özellikle kişisel ve kişilerarası nostaljinin öne çıktığı görülmüştür. Ayrıca nostalji içeren reklamların katıımcıları satın alma gibi davranışa yöneltmeden ziyade duyguları tetiklediği saptanmıştır.

Anahtar Sözcükler: Nostalji, Nostaljik Reklamlar, Retro Reklamlar

JEL Sınıflandırması: M37, M30

\section{Nostalgia from the Younger Generation Perspective: The Impact of Nostalgia Advertising on Postmodern Individuals}

\begin{abstract}
Companies need to find new branding and marketing strategies to overcome the problems rising from the intense competition in every sector and increasing consumer expectations. While searching for new tactics to attract consumers' attention and moreover position their brand in the mind and hearts of their target groups, nostalgia and retro marketing offers many advantages. The rising trend of nostalgia in advertisements revealed the necessity of investigating effectiveness. The aim of this study is to determine the nostalgia trend among postmodern individuals who are born between 1980-1985, and analyze their approach to nostalgia theme used in advertisements. Survey method is used to examine the nostalgia proneness and effectiveness of nostalgia advertisements. According to findings, personal and interpersonal nostalgia is more prominent among respondents and nostalgia ads are effective in triggering consumers emotions rather than directing their consumer behavior.
\end{abstract}

Keywords: Nostalgia, Nostalgia Advertising, Retro Advertising

JEL Classification: M37, M30

\footnotetext{
${ }^{a}$ Assist. Prof. Dr., Okan University, Istanbul, Turkiye, ebru.guzel@okan.edu.tr

${ }^{b}$ Assoc. Prof. Dr., Yeditepe University, Istanbul, Turkiye, eokan@yeditepe.edu.tr
} 


\section{Giriş}

Hızla artan rekabet, markaları tüketicilerin aklına ve kalbine hitap edecek yeni pazarlama stratejileri kullanmaya yönlendirmektedir. 1990'lardan itibaren özellikle pazarlama iletişiminde kullanılmaya başlayan nostalji teması, tüketicileriyle duygusal bağ yaratmayı hedefleyen firmalar ya da markalar tarafından sıklıkla başvurulan bir unsur olmuştur. Odabaşı'na göre, postmodern bireyler, geçmişle bağ kurmaktan ve onu bugüne taşımaktan büyük zevk almaktadırlar. Aslında geçmişle geleceği bir arada içeren, ne geçmişe ne de geleceğe tek başına bağlamak yerine, şimdiyi yaşamak eğilimi gösteren postmodern bireyler, geleceği nostalji ile oluşturmayı tercih etmektedirler. Odabaşı, bu durumu eski ürünlerin nostaljik olarak yeniden tasarlanması üzerine oluşturulan ve postmodern pazarlama trendi olarak gösterdiği geleneksel ev reçelleri ya da makarna firmalarının yeniden keşfettiğini erişte örnekleriyle açıklamaktadır (2004: 84-85).

80'li yıllarda aniden ortamın değişmesiyle birlikte eyleyenin, öznenin, bireyin dönüşüne de tanıklık edilmiştir (Üskül-Engin, 2005:140). Modernizme kültürel bir eleştiri olarak doğan postmodernizm (Turner, 2002:274) ve bu yaklaşımın tanımladığı postmodern birey; kişisel anlam arayışında olan, gerçeklik iddiasında bulunmayan, anlık isteklerinin tatmiyle hareket eden, bağlılıklarından özgürleşmiş bir bireydir (Rosenau, 1998: 97-98). Modernizmin geleceğe yönelik tasarımına karşın postmodernist yaklaşımda gelecek ve geçmişle bağların koparılmaması amaçlanmaktadır (Yeygel, 2006:208): "Postmodern bireyin birçok şeyi birlikte aynı anda denemek istemesi eğilimi, belki de geçmiş ve geleceğin birlikte denenebileceği algısını yaratmaktadır". Bu anlamda nostalji kavramı postmodern bireyler için önem kazanmakta, bir postmodern pazarlama stratejisi olarak nostaljik içerikli reklamlara yer verilmektedir.

Nostaljinin postmodern pazarlama içinde kullanılması, hedef kitle olarak postmodern bireylerin doğrudan ya da dolaylı deneyimine başvurması, nostaljinin etki alanını genişletmiştir. Nostaljiyi özellikle emeklilik yılları ya da yaş ilerledikçe beliren bir tercih olarak değerlendiren görüşlerin aksine, daha genç yaşlarda beliren bir eğilim olarak gören araştırmalar da bulunmaktadır. Kişilerin anlam, değer, amaç ve farkındalık arayışında, geçmiş deneyimlerin pozitif tortusu, nostaljiyi yaşla sınırlandırılamayan ve kuşaklara özgü değerlerin birleştirici etkisi olarak ortaya çıkarmaktadır. Ayrıca internetin gelişimi ve yaygın kullanımı ile birlikte zaman ve mekan sınırlamasının olmadığı sosyal medya ağlarında gençler, gerçeklikten uzak sanal ilişkiler yaşamaktadırlar. Her geçen gün teknolojik gelişmelere tanıklık eden bu postmodern bireyler için sosyal medyanın kullanılmadığı yakın geçmişin yüz-yüze, sıcak ilişkilerden oluşan anılarına ve dolayısıyla gerçekliğe sığınma isteği nostaljiyi, alternatif bir seçenek olarak göstermektedir.

Nostalji olgusunun daha genç bireyler üzerinde de etkili olduğunu gösteren Hemetsberger, Kittinger-Rosanelli ve Mueller (2012)'in araştırma bulgularına göre, genç tüketicilerin de nostaljiye karşı eğilimli olduğunu belirtilmiştir. Gençlerin nostaljiye karşı duyarlı olması, içinde bulunduğumuz bilişim çağına özgü iletişim ve teknolojik gelişmelerdeki hızla bağlantılı olabilmekte, beş-on yıl öncesine ait teknolojik bir ürün antika olarak anılabilmekte; bugün gelinen noktada artık dijital nostaljiden bahsedilmektedir. Hızla değişen yaşam koşullarının da etkisiyle nostaljinin daha genç yaştaki bireylerle ilişkisini ortaya koyan yeterli yayının olmayışı araştırmanın önemini de vurgulamaktadır.

Nostaljik içerikli reklamların postmodern bireylerle ilişkisinin araştırıldığı bu çalışmanın amacı, 19801985 yılları arasında doğan postmodern bireylerin, nostaljiye karşı yaklaşımlarını araştırmak ve reklamlarda kullanılan nostalji unsurundan etkilenip etkilenmediklerini öğrenmektir. Bununla birlikte nostalji eğiliminin farklı boyutlarının araştıııması, nostaljinin satın alma davranışlarıyla ilişkisini de ortaya koyacağı düşünülmektedir. Kavramsal çerçeve dahilinde başlayan araştırmada, nostalji ve reklam konusunda literatürde yer alan çalışmalar aracılığı ile yazın taraması yapıımıştır. Araştırmanın yöntemi ve bulguların yer aldığı bölümlerin ardından çalışmanın sonunda, kısıtlar, öneriler ve yorumlara yer verilmiştir. 


\section{Kavramsal Çerçeve}

\subsection{Nostalji ve Gençler}

Belk tarafından "üst-gerçeklik" (hyperreallity) ile bağdaştırılan nostalji kavramı, belirsizlik ve güvensizlik duygularının yaşandığı modern toplumlarda güvenli bir liman olarak algılanmakta ve "... bir obje, sahne, koku veya müzik tarafından harekete geçirilen özlemli bir duygu durumu" (1990:670) olarak açıklanmaktadır. Insanlardaki nostaljiye dayalı romantik tavır, kapitalist/modern gerçekliğe olan muhalefetten doğmaktadır (Löwy \& Sayre, 2016:35). Çağın olumsuz koşullarını tersine çevirecek türden, Davis'in (1979) "süreklilik arayış" betimlemesiyle özetlenebilen nostalji, bireyleri üst-gerçeklikteki bir dünyaya davet etmektedir. Güncel gerçekten kaçarak korunaklı bir adrese ya da bugünün koşullarına göre, dijital dünyanın sanal ilişkilerden anılarındaki gerçekliğe sığınmayı tercih eden bireyler için nostalji, alternatif bir yol olarak belirtmektedir.

Sedikides vd. (2008:307) tarafından geçmiş, bugün ve gelecekle ilişkisinin araştırıldığı çalışmada nostaljinin dört psikolojik işlevi olduğu dile getirilmektedir:

1) Pozitif etkiler üretmek (it generates positive affect),

2) Özsaygıyı yükseltmek (levates self-esteem),

3) Sosyal bağları teşvik etmek (fosters social connectedness),

4) Varoluşsal gerilimleri iyileştirmek (alleviates existential threat).

Bu dört işlevinden dolayı nostalji, günlük yaşamın iniş çıkışlarını dengeleyen, insanları motive eden, geçmişle bugün arasındaki sürekliliğin sağlanmasına aracılık eden ve özsaygıyı olumlayan bir unsur olarak belirmektedir. Bütün bu olumlu işlevlerine rağmen Sedikides vd. tarafından olumsuz ruh hali ve yalnızlığın nostaljiyi tetikleme nedeni de sorgulanmıştır. Olumsuz psikolojik durumlarda nostaljinin sıkıntıyı ortadan kaldıran ve sakinliği geri getiren bir kapasiteye sahip olması (2008:305), nostaljiyi güçlü kılan bir diğer unsur olarak göstermektedir.

Geçmiş, eski ya da geleneksellik vurgusundan çok daha geniş bir anlam içeren nostalji kavramı dört kategoriye ayrılmaktadır: Doğrudan bireysel deneyimden oluşan "kişisel nostalji (personal nostalgia)", bir başkasının yaşadığı deneyime dayanması sonucu dolaylı olarak oluşan "kişilerarası nostalji (interpersonal nostalgia)", doğrudan kolektif deneyime dayanan "kültürel nostalji (cultural nostalgia)" ve dolaylı kolektif deneyime dayanan "canlandırılmış nostalji (virtual nostalgia)" (Holak vd., 2006:195). Kişisel ve kişilerarası nostalji bireysel olana işaret ederken, kültürel ve canlandırılmış nostalji ise kolektif olana işaret etmektedir. Buna karşın kişisel ve kültürel nostalji doğrudan deneyime dayanmakta, kişilerarası ve canlandırılmış nostalji ise dolaylı deneyimden oluşmaktadır (Tablo 1).

Tablo 1. Nostalji Kategorileri

\begin{tabular}{|l|lll|}
\hline \multicolumn{2}{|l|}{ Sosyal deneyim } & Bireysel & Kolektif \\
\hline Deneyim Türü & Doğrudan & Kişisel nostalji & Kültürel nostalji \\
& Dolaylı & Kişilerarası nostalji & Canlandırılmış nostalji \\
\hline
\end{tabular}

Kaynak: Holak vd., 2006:196.

Kişisel nostalji, bireylerin duygusal deneyimlerine dayanarak hafızada yer eden anılardan meydana gelmektedir. Bireylerin çocukluğunda dinlediği masallar ya da gençlik yıllarında izlediği filmler, bizzat kendisinin deneyimlediği her duygu, olay, kişi ya da nesne bu gruba dâhil olmaktadır. Örneğin bir reklam filminde seksek oynayan bir çocuğun görüntüsü, bireye hızlı bir içe dönüş anı yaratmakta; çocukluğundaki masum duyguları yeniden yaşatabilmektedir. Özellikle ileri kapitalist ekonominin yoğun olarak hissedildiği metropol yaşantısında postmodern bireyler, ideallerini çocukluk yıllarında aramak, değerlerinin korunaklı olduğu geçmişi hayal etmek için yaş almayı beklememektedirler. Bu düşüncenin bir tezahürü olarak bireyler şehri terk edip köye gitmek, modernden kaçıp egzotik olana sığınmak, uzam içinde yer değiştirerek "şimdi" nin içinde geçmişi aramakta (Löwy \& Sayre, 2016:42) ve kendilerine geçmişle şimdinin buluştuğu bir 
gerçeklik yaratmaktadırlar. Modern çağın kişiler üzerinde yarattığı yabancılaşma, yalnızlaşma ve mekanikleşme gibi toplumsal sorunlar düşünüldüğünde kişisel nostaljiyi yaşama yaşının gerilediği öngörülmektedir.

Bugün 20'li yaşların başında olan bir gencin kendi yaşamadığı halde ailesinin yaşadığı dönemsel bir öyküye, geçmişteki bir deneyime ya da tarihin bir kesitine sempati duyması kişilerarası nostalji kavramıyla açıklanmaktadır. Örneğin bir bireyin anne ve babasının yaşadığı 1960'lı yıllarda başlayan Hippi Akımından ilham alınarak, yeniden üretilen Volkswagen'in ikonik Hippie-van aracına sempati beslemesi bu gruba özgü bir eğilimdir. Bununla birlikte bireyler, ailelerinden dinlediği, retro filmlerde ya da antikacılarda gördüğü çevirmeli sabit telefonların, siyah-beyaz televizyonların ya da gramofonların hissettirdiği "eski günler, bugünden iyiydi" duygusunu yaşatma eğilimde olabilmektedirler.

Kültürel ve canlandırılmış nostaljiye bakıldığında, toplumsallık vurgusu her ikisi için de geçerliyken, canlandırılmış nostalji, anlatılan geçmişle doğrudan deneyimin olmadığı "tarihi nostalji" (Stern, 1992:389) kavramıyla açıklanmakta ve dolayısıyla tarihsel belge, kitap ya da video gibi dokümanlar aracılığıyla yeniden üretilmektedir. Bireylerin ya da toplumların tarihsel olayları kendi nostalji duygularıyla özdeşleştirme eğiliminde olması, canlandırılmış nostalji aracılığıyla tarihin kurgusal yeniden üretimini değerli kılmaktadır. Örneğin bazı televizyon programlarında gazilerin konuşmaları bireyleri hiç yaşamadığı Kurtuluş Savaşı ortamına götürmekte, dolayısıyla ona ilişkin zihinlerinde yer eden duygulara çağrışım yapabilmektedir. Aynı şekilde reklamlarda kahraman imgelerinin kullanılması tarihten bir kesiti ve ona özgü kolektif anlamları izleyiciye aktarmaya aracılık etmektedir.

Deneyimin gerçekliğiyle canlandırılmış nostaljiden ayrılan kültürel nostaljide, aynı tarih kesiti içinde, aynı özlemleri yaşayan insan grubu ya da toplumlar anlatılmaktadır. Türklerin toplumsal hafızasında yer eden bayramlar, yabancıların ise Hallowen (Cadılar Bayramı) ya da Noel gibi gün ya da haftalara özgü ritüelleri buna örnek olarak verilebilir. Özellikle Kent Şekerleme Firmasının, modernizmin tehdit ettiği geleneksel değerleri hatırlatan ve nesillerin geçmişe özlemle bakmasını sağlayan "Nerede o eski bayramlar?" vurgulu reklamı, hafızalardan çıkmamıştır. Bir tersine düşünüş olarak geçmişin kötü izlerine gönderme yaparak şimdiyi olumlayan reklamlarda da korkunç tarihi kahramanlara yer verilebilmektedir. Her iki durumda da toplumun genç, orta ya da yaş almış bireylerinin bu reklamlardan etkilenmesinin altında postmodern yoruma özgü geçmişle olan bağların koparılmaması ya da eleştirel bir ifadeyle modernizmin "şimdi"sinin yanına geçmişi koyma isteği yatmaktadır.

Davis, bireylerde gözlenen bu nostaljik duyarlılığın özellikle orta yaş ve "emeklilik" yıllarında zirveye ulaştığını ileri sürmektedir (Davis, 1979:17). Ancak nostaljinin yaş ilerledikçe belirlenen bir tercih olarak değerlendirilmesine karşın, genç tüketiciler için de geçerli olduğunu gösteren araştırmalar da bulunmaktadır. Hemetsberger, Kittinger-Rosanelli ve Mueller'in, “Grandma's Fridge is Cool: The Meanning of Retro Brands for Young Custumers" başıkılı makalesinde, genç tüketicilerin de nostaljik olabildiği iddia edilmektedir. Araştırma bulgularına göre bazıları ebeveynlerin deneyimlerinden oluşan duyguları yansıtsa da, gençlerin çoğunlukla çocukluktan, yaşadığı anlamlı anlardan, erken deneyimlerden ve alışkanlıklardan doğan bir kavram olarak nostaljiyi sevdikleri dile getirilmektedir. Bununla birlikte genç tüketiciler nostaljik markalarla sürdürülen geleneksel ritüellerin anlamlarını, sahip oldukları toplumsal amaçlar doğrultusunda yeniden yorumlamakta, bundan dolayı da nostalji, kişilik ve bireyselliği gösteren bir ayna görevi görmektedir (2012:242). Örneğin kötü bir çocukluk yaşantısına sahip olan bir bireyin, o yıllara çağrışım yapan bir reklamı olumsuz bulmasıyla aslında kişiliğinin bir özelliğini yansıtabilmekte; bir anlamda nostaljik reklam, neyi sevip sevmediğinin göstergesi olarak belirebilmektedir. İleri yaşlarda, kişiliği oturmuş, yaşam amacı farklılaşmış bir bireye karşın, daha genç yaştaki bir yetişkin için nostalji ayna işlevi görebilmektedir.

Kişilerin anlam, değer, amaç ve farkındalık arayışında nostaljinin; yaşanmışlıkların, geçmişe dayanan referansların, gençler tarafından da önemsenmesi çağa özgü bir olgu olarak belirmektedir. Dijitalleşmeyle birlikte X (1965-1979), Y (1980-2001) ve Z (2000-2020) kuşakları (Alwin, 2002) arasındaki sınırların teknolojik belirleyiciliği, yakın gelecekte dijital nostalji kavramından daha sık bahsedilmesine neden olacaktır. Küresel ölçekte dijital teknolojilerin bireylere zaman ve mekandan tecrit deneyimler yaşatması, dijital nostaljiyi bu deneyimleri analiz etmek için kritik bir araç olarak konumlandırmaktadır (Estevez, 
2009:1). Farklı kıtalarda yaşayan bireyleri aileleri veya eski arkadaşlarıyla buluşturan sosyal ağlarda kurulan eşzamanlı, çoklu ve mekansızlık hissi yaşatan ilişkiler, nostaljiyi, dijital platformlara taşımaktadır. Bunun yanı sıra mobil teknolojilerinin hızlı gelişimi ile birlikte, Nokia ve Ericsson gibi markaların cep telefonlarının bugün birer antikaya dönüşmesi gibi, çevrimiçi sohbet programları (Yonca, Mynet, ICQ gibi) da yakın bir geçmişi olmasına rağmen, artık nostaljik ürünler kategorisinde anılmaktadırlar. Farklı bir açıdan bakıldığında örneğin Y Kuşağı üyeleri tarafından kullanılan ve bugün neredeyse unutulan MSN Messenger (1999-2005), Windows Live Massenger (2006-2013) gibi mesajlaşma servisleri, aynı kuşağın üyelerince kişisel nostaljiyi oluştururken, bir kuşak sonrası için kişilerarası nostalji sınıfında değerlendirilebilmektedir.

Nostaljinin ikna edici yapısı ve marka mirası yaratmadaki katkısı günümüzde yeni pazarlama yöntemleri kapsamında değerlendirilmektedir. Marka mirası kavramı pazarlama karmasının değişkenleriyle birlikte algılanmakta ve belli bir markanın tarihini anlatmaktadır (Brown vd., 2003:20). Marka kimliği ve imajının oluşumunda önemli bir rol oynayan marka mirası, (Gökaliler \& Aslan, 2015:258) tüketicilere güven duygusu sağlamakta ve markanın rakiplerinden farklı olarak konumlanmasını sağlamaktadır. Geçmişe ait güvenli duyguların yeniden canlandırıldığı nostaljik reklamlar, özellikle köklü markaların marka kimliğini, marka imajını ve de marka mirasını olumlayan nitelikte oluşturulmaktadır. Burada yine şimdinin yarattığı belirsizlik, güvensizlik, değişkenlik ve süreksizlik tehdidi gibi tüm olumsuz duygular, nostalji vaadiyle pozitife dönüştürülmeye çalışılmaktadır. Aslında nostaljik unsurlara reklam söylemi ekseninde negatif ya da pozitif anlamlar yüklenerek sunulması yoluyla ideolojik olarak, kapitalist sistemin yarattığı pek çok olumsuz his durumunu manipüle edilmekte, "süreklilik", "aidiyet", "güvenirlik", "doğallık" ve "köklülük" gibi yeni anlamlar üretilmektedir (Taşkaya, 2013:30). Kısacası modern pazarlamanın vurguladığı "yeni" kavramına tezat olarak postmodernizmde geçmişe verilen bir değer olarak nostalji kavramı öne çıkmakta, postmodern markalama stratejisi olarak imaj, sembol ya da gösterge gibi nostaljik unsurların kullanıldığı retro reklamlar aracılığıyla geleneksel markalar yeniden yaratılmaktadır.

\subsection{Reklamın Postmodern Yorumu ve Retro Reklamlar}

Reklamın toplumun kültürel iklimi üzerinde pek çok etkisi bulunmaktadır. Genel anlamda reklam, satışa yönelik ürün ya da hizmet hakkında hazırlanmış iletilerin tüketiciyle buluşma noktası olmaktan öte bir içeriğe sahiptir. Modern toplumlarda tüketim olgusu, tüketicileri ve tüketim ürünlerini anlamın aktarıldığı istasyonlar olarak algılamayı sağlarken, reklam da bu anlamın hareketini sağlayan bir araç olarak görülmektedir (Ulusoy, 2005:20-21). Reklamın doğasına uygun olarak yaratılan her yeni anlam, tüketicileri ihtiyaçlarından türetilmiş bir kozmosa davet etmektedir. Postmodern yaklaşımla bu yeni anlam, üstgerçeklikte kurgulanan reklamdaki kodların içinde sıklıkla yer almaktadır.

Bir reklamın etkisinin dağıık ve uzun süreli olmasının yanı sıra reklamın, genel ve antropolojik manada, "gerçekliği" belirlemede rolü yadsınamaz (Dyer, 2010:120). Baudrillard'a göre içinde yaşadığımız bu simülasyon evreninde nesneler, özgün anlamlarından yoksun, seyirlik şeyler halinde düzenlenmiştirler. Nesneler meta olma özelliğini yitirerek, pek çok anlam ve mesaj taşıyan "gösterge"lere dönüşmekle kalmamış, medya mesajları da benzer bir şekilde tüketici tarafından çözülmeyi beklemektedir ([1998] 2011:111-112). Gerçekliğin bile gerçekliğini yitirdiği bir çağda kurgulanan her gösterge, reklamların içinde gerek dil yoluyla, gerekse görsel ya da metaforik anlatımlarla yer almaktadır.

Başka bir ifadeyle reklamlar aracılığıyla bir "şey"in anlamı başka bir şeye yüklenmekte ya da göstergeler arasında anlam aktarımı sağlanabilmektedir (Dyer, 2010:168). Örneğin bir mücevher markasının reklam filminde yer alan pırlanta yüzük, sevginin yerine geçerek, onu yeniden temsil etmektedir. Bu temsil, reklamın, bir ürün hakkında gerçekleri beyan etmek yerine, bir çözüm ya da hayal satmak amacına işaret etmektedir (Kotler, 2015:141). Hepsinden önemlisi bir marka yaratmak ya da mevcut bir markayı yeniden konumlandırmak gibi bir amaçla markaya dair tutundurma faaliyetleri içinde büyük bir işlevi olan reklamın, yeni nesil tüketici gözünden yeniden yorumlanması önem taşımaktadır.

Bu öneme biyolojik temelli açıklama getiren Zaltman, ses, hareket, ruhsal durum ya da duyguların nöronsal faaliyetleri uyarabildiği için reklamlardaki kullanımlarına dikkat çekmekte ve Coca-Cola markasının bir radyo reklamını örnek göstermektedir. Reklamda duyulan kapağın açılış sesi gibi kola içmeye özgü 
herhangi bir faaliyet, direk olarak bir kolaya uzanıp onu tattığınız anı hatırlama işlevi görmektedir. Zaltman bunun nedenini, düşüncenin kelimelerden yalıtılmış salt imgelerle ilişkisine dayandırmaktadır. Reklamlarda imge, sembol ya da göstergelerin dolaşıma sokulmasıyla, izleyici uyarılmakta, çoğunlukla bilinçdışı yollarla satın alma davranışına yönlendirilmektedir. Kelimelerin düz anlamla ifade edilemeyen kavrama sürecinin ise metaforlar aracılığıyla sağlandığını anlatan Zaltman, dil ile ifade edilemeyen düşüncelerin de bu yolla oluşturulduğunu aktarmaktadır (2003: 66-118). Örneğin kimi otomobil reklamlarında gerçeküstü görüntüler eşliğinde daracık yollardan son sürat geçen erkek sürücüler genellikle güçle ilişkilendirilirken, kadınlar ise bedene indirgenen bir nesnellik kurgusu içinde, arabanın estetik bir uzantısı olarak konumlandırılmaktadır. Bazı reklamlarda anlamlar kümesi daha karışık olabilmekte; örneğin hızla giden bir otomobil izleyiciyi düş dünyasına davet ederken, araba da oyuncaklarla ya da dış dünyanın karmaşasından kaçarak sığınılan ana rahmiyle ilişkilendirilebilmektedir (Rutherford, 2000:28-29):

Işyerinden çıkan başarılı bir işadamı olduğunuzu varsayalım. Geride yumuşak bir müzik çalmaktadır. Peugeot 605 otomobilinize bir işaret çakıyorsunuz, kapıların kilidi açılıyor, yalnız sizin için. Otomobilinize biniyor ve arkanıza yaslanıyorsunuz. Günün yorgunluğu omuzlarınızı terk etmeye başladı bile. Garip bir biçimde boş olan kent sokaklarında giderken kaldırımlarda acele acele yürüyen kalabalıkları görmektesiniz. Gerçekten her şey son derece hızlı. Üzerinizde vinçler dönüyor, bir köprünün altından trenler kurşun gibi geçiyor... ama hiç biri size dokunamıyor, otoyola çıkınca camınızı kapatıyor ve kendinizi trafikten soyutluyorsunuz. İçerideki ısıyı bile, bir düğmeye dokunmakla ayarlayabiliyorsunuz. Sonunda kentin dışındaki malikânenize ulaşıyorsunuz, yolculuğunuz kolay geçtiği için dinlenmişsiniz. Bir dış ses sesleniyor: "Dünya yanınızdan uçup giderken rahatlayın." (Rutherford, 2000:28-29).

Düşler dünyasına kaçma fantezisinin reklam yoluyla üretiminde bir başka pazarlama stratejisi de reklamda nostalji öğesinin kullanılmasıdır. Geçmişe duyulan özleme, dünü yad etmeye, sahip olunan şeylere düşkünlüğe ve geçmişte yapılan aktivitelere referans veren nostalji (Holbrook, 1993:249) kavramı, reklamlarda kişilerin on ile yetmiş yıllık geçmişinin bir tasviri olarak yer bulmaktadır (Holbrook \& Schindler, 1989:122). Bir reklamda geçmişe ilişkin herhangi bir sembol ya da gösterge, zihne projeksiyon tutarak bir anıya çağrışım yapabilmektedir. Örneğin General Motors firması, her kültürün sosyal hafızasında yer eden Kırmızı Başlıklı Kız hikâyesini kullanarak, özdeşleştiği Ormancı karakteriyle tehlikeli yollardaki kurtarıcı rolünü üstlenmiştir (Zaltman, 2003:293). General Motors firması bu sayede tüketicilerin kolektif zihinlerinde çocukluk yıllarında yer etmiş ve güvenle sembolleşen göstergeleri hatırlatarak, masala özgü olumlu bütün değerleri marka kimliğine transfer etmeyi başarmaktadır.

Tüketim olgusunun teknoloji ve iletişimle hız kazandığı ve her şeyin dijitalleştiği bir çağda, bireyler, tektipleşme, yalnızlaşma ve nesneleşme tehlikesiyle karşı karşıyadırlar. Reklam iletilerinde nostaljik kurgular geçmişin olumlu duygularını hatırlamanın yanı sıra bireye özgünlük, farklılık ve aidiyet hisleri de yaşatmaktadır. Davis'e göre, nostalji, yaşanmış geçmişi olumlu bir şekilde hatırlattığı gibi şimdi ve geleceğin olumsuz etkilerini olumlu değerlendirmeye dönüştürmeye yardımcı da olmaktadır. Onun tanımıyla "geçmişin olumlu çağrışımları anın ve geleceğin olumsuzluğunu içerirken dünün bugünden daha iyi olduğu inancından tecelli eder" (1991:18) cümlesiyle nostaljiyi pozitif bir değer olarak vurgulamaktadır. Örneğin reklamlarda Marilyn Monroe mitinin veya reklamla uyumlu bir bağlantı kuran Hotel California müziğinin kullanılması özellikle Baby-Boomers (Bebek Patlaması) Kuşağı üyeleri ve onların çocuklarına, tanıdık olanın sıcaklığını duyumsatacak nostaljik bir deneyim yaşatmaktadır.

Postmodern pazarlamanın yeni ürün ve hizmet yaratma stratejisine tezat gibi dursa da, aslında bir alternatif olarak görülebilen bu yeniden üretilen geçmiş, retro pazarlama olarak kuramsallaşmıştır. Retro pazarlama, geçmişteki bir ürün ya da hizmetin günümüz koşullarına göre yeniden revize edilerek canlandırılma süreci olarak tanımlanması bakımından nostaljiden güncellik farkıyla ayrımaktadır (Brown vd., 2003:20). Bir başka anlatımla retro pazarlama, ürünlerin tekrar revize edilerek nostalji temelli pazarlama çalışması ekseninde pazarda yer almasıdır (Gökaliler \& Aslan, 2015:244). Mont Blanc Fountain kalemi, Converse All Star ayakkabısı ya da Wispa markasının Candbury Çikolataları yeniden revize edilen ürünlere örnek olarak verilebilir. 
Postmodern pazarlama anlayışında eski ve yeniyi sentezlenme eğiliminin bir çıktısı olarak değerlendirilebilen retro reklamlarda tüketicilerin geçmişe götüren kişi, nesne, müzik, dekor, hayvan gibi pek çok gösterge kullanılmaktadır. Retro reklamlarda kullanılan geçmişle bağı olan herhangi tanıdık bir simge, markanın müşterisiyle kurduğu duyu temas noktasının sağlamlamasına yardımcı olmaktadır. Geçmişin idealleştirilmesiyle, korunaklı bir alanda çocukluğundaki gibi sıcak duygular yaşayan tüketicilere, bu dünyayı hatırlatmak için bir logo dahi yeterli olabilmektedir. Ayrıca retro reklam kampanyalarında, postmodern markalama çalışması olarak kullanılan "otantiklik" kavramı, marka sadakatinin ve marka mirasının güçlenmesine de yardımcı olmaktadır.

\subsection{Retro Reklamların Gençlere Özgü Nostaljik Mesajları}

Bir ürün ya da hizmete yönelik yüzlerce çeşidin olması pazara yeni girecek markaların bilinirlik yaratmasını zorlaştıran faktörlerin başında gelmektedir. Buna karşın eski bir markayı yeniden canlandırmanın cazip hale gelebilmesinde nostaljinin payı yadsınamaz. Bir markanın bellekteki temel öğelerinin merkezinde yer alan ad ve simgelerin bilinirliği (Franzen, 2002:185) modeline göre, reklamda nostalji unsurunun kullanımıyla işlevsel ve duygusal bir etki yaratılabilmektedir. Belirli duygularla ilişkilendirilen markalara ait retro reklamlarda nostalji öğelerini içeren pek çok mesaj bulunmaktadır.

Tüketiciyle duyusal bağ yaratarak ulaşabilecek son düzeye geçen (Lindstrom, 2007:126) ve yıllarca var olmayı başaran markalar, reklamlarında nostalji kullanımıyla sinerji yaratmayı hedeflemektedir. Örneğin; Chanel No.5 Parfümü, 1921'den günümüze bir klasik olarak Marilyn Monroe'nin yer aldığı reklam ile ölümsüzleşmiştir. Çağdaş mitlerin reklamda kullanılması yoluyla çelişkilerin çözümü, kimlik modeli yaratımı ve toplumsal düzen sağlanmaktadır (Kellner, 1992:158; Aktaran Dağtaş 2003:94). Reklamda star kullanımıyla verilen mesaj açıktır; bir yanda parfümü satın alan kadınların Monroe mitiyle özdeşleşmesi sağlanırken, diğer yandan Monroe'nun bütün kişilik özellikleri markaya transfer olmaktadır.

İmparatorlukları, dinleri, kültürleri, kısacası evrensel tüm değerleri içeren ve dünyanın her yerine yayılmış olan ikonlar doğrudan olduğu kadar, dolaylı olarak da mesaj taşımaktadır (Lindstrom, 2007:187). Örneğin; Algida markasının kalp şeklinde logodan oluşması, reklamlarında kullanılan aşk, sevgi, arkadaşlık ve aile temalarıyla çok örtüşmektedir. Bu tip reklamların pek çok nostaljik etkileri olabilmektedir: Sahilde yakışıklı genç bir erkeğin, güzel bir genç kadınla bakışarak dondurma yemeleri, izleyicide ergenlik dönemine ait flörtü hatırlatabilmekte, geçmişte kalan heyecanlı günleri yeniden yaşatmakta ya da reklamdaki kadın ya da erkek oyuncu aracılığıyla izleyicinin idealindeki partnere çağrışım yapılabilmekte ve bu yolla ihtiyaç duyulan, belki de erişilemeyen bütün duyguların tatmini sağlanabilmektedir. Algida reklamlarında nostaljiden payını alan sadece gençler değildir. Çoğunluğu ergenler ve çocuklardan oluşan bir grubun rol aldığı "Yağmur Reklamı”nda, Barış Manço'nun “Anlıyorsun Değil mi?” Şarkısının yeniden uyarlanması yoluyla, bir zamanlar çocukların arkadaşı olarak sembolleşen Barış Manço'ya ait tüm algıların yeniden üretilmesi ve bunun ergenler ve çocuklara aktarılarak birlikte paylaşılması sağlanmaktadır. Aynı şekilde geleneksellik vurgusunun ön planda olduğu "Maraş Usulü Klasik Dondurma” reklamında da, kültürel değerlere ait mesajın dededen toruna aktarılması amacıyla, kalabalık iftar sofrası kullanılmış; dolayısıyla reklamda kültürel nostalji teması işlenmiştir.

Günümüzde gençler için nostaljik anlam taşıyan ya da nostalji algısı yaratması hedeflenen tarih, mekan, simge ya da semboller, onların yoğunlukla kullandığı sosyal medya ağlarında yayınlanan reklamlarda da sunulmaktadır. Geçmişe duyulan özlemi sosyal medyaya taşıyan reklam kampanyalarında, kişilerin katılımına imkân tanıyan uygulamalara da yer verilmektedir. Örneğin Facebook, ya da Twitter'da paylaşılan reklam görsellerine yorum yapılması istenmekte, içerik paylaşan kullanıcıların nostaljiye katılımı sağlanmaktadır. Buna bir örnek olarak, yerel bir marka olan Pino Lezzet Durağı'nın "bir zamanlar" etiketiyle paylaştığı sosyal medya reklamı verilebilir. Reklamda sadece 38 yıllık bir geçmişe sahip olan (http://www.pino.com.tr) bir markanın güvenilirliği vurgulanmamış, aynı zamanda kullanıcılardan geçmişe ait anılarının paylaşımı istenerek bir anlamda nostalji grubu yaratılmaya çalışılmıştır. Geçmişin sıcak duygularını hedef alan bu ortak algı yaratımında nostalji kavramı çatı görevi görmekle birlikte, yaşanmışlıkların yaşla sınırlandırılmaması ve kuşaklara özgü nostaljik değerlerin birleştirici etkisi de ortaya çıkmaktadır. Tabi buradaki nostalji grubunu genç kuşaklar oluşturmaktadır; çünkü hem seçilen mecranın bir 
sosyal medya platformu olması, hem de hamburger yiyen kesimin çoğunlukla genç insanlardan oluşması grubu tanımlayan önemli bir kriterdir. Kısacası Instagram'da yayınlanan Pino markasının retro reklamında, "bir zamanlar" etiketinin altına fotoğraf yükleyen ve yorumda bulunan kullanıcılardan oluşan bir çevrimiçi grubunun varlığı ve nostaljik paylaşımları aracılığıyla bir değer yaratmak amaçlanmıştır.

Köklü bir çikolata ve şekerleme firması olan Eti Gıda Firması da, Wanted Çikolatasına ait retro reklamlarında nostaljiden yararlanmıştır. Reklam serisinin tamamında eski bir Amerikan Dizisine gönderme yapılmaktadır. 1980'lerin polisiye temalı televizyon dizisi Starsky and Hutch'dan esinlenerek yapılmış reklam filminde kullanılan retro araba, giysiler ve iki dedektiften oluşan nostaljik karakterler aracılığıyla, postmodern tüketiciye geçmişiyle bağ kurdurmaya çalışıımıştır. Bir başka açıdan geçmiş yılların bir fenomeni olan bu diziyi izleyen, ailesinden ya da çevresinden duyan (markanın çikolata firması olmasından dolayı daha çok gençlerden oluşan) hedef kitlenin, absürt komedi şeklinde hikayelendirilen bu nostaljik reklamdan zevk alması düşünülmüştür. Tabi burada gençlerin ilgisini çekmek için Starsky and Hutch Dizisi'nin seçilmesinde, dizinin 2004 yılında sinema filmi uyarlamasının bulunması ve başrolünde Ben Stiller, Owen Wilson gibi gençlerin çok sevdiği aktörlerin yer alması da önemli bir etken olabilmektedir. Ayrıca benzer bir biçimde Seksenler adlı dizinin dört yıldır yayında kalması, eski müziklerin, filmlerin, retro kafelerin ya da Karaköy, Galata gibi bölgelerin popülerleşmesi gençlerin nostalji algısına karşı sempati beslediğinin göstergeleri olarak yorumlanabilmektedir.

Görüldüğü gibi ünlü kişilerin, mekanların, filmlerin ve şarkıların nostalji konseptiyle buluştuğu retro reklamlar bazen seri halde üretilmekte; reklamda nostaljik öğe olarak izleyicilerin aşina olduğu, ilgi duyduğu konular, hikayeler, mekan, ikon ya da göstergeler işlenebilmektedir. Nostaljik temalı reklamların bazıları eski hikâyelerden oluştuğu gibi, bazıları da zaman içinde farklı açılımlarla süregelmektedir. Nostaljiye yeni açıımlar katan başarılı dizi reklamlar içinde bir sinema filmi olarak öne çıkan Yıldız Savaşları (Star Wars), 1977 'den günümüze değin efsaneleşerek süregelen bir sinema serisidir. George Lucas tarafından tasarlanan ve 2015 yılının son ayında yedincisinin vizyona girdiği film serisi, kitapları, televizyon dizileri, giyim eşyaları, internet oyunları, oyuncakları ve çizgi romanlarıyla ikonlaşmış bir markadır. Lucas'a göre, retro özelliği taşıyan son Güç Uyanıyor (Force Awekens) Filmi, izleyicisine nostaljik tatmini vaat etmektedir:

\footnotetext{
“... Retro kültür ise nostaljik insanın kurduğu altın çağın hassasiyetlerini taklit ederek hafızayı hareketlendirmeyi ve böylece kaybedilmiş geçmiş ile bugünün bağlarını kurdurmayı amaçlıyor. Bunun için de duyuları geçmişte karşılaşılmış ses veya görüntülerle uyarmak en başat yöntem. Yani ekranda, imparatorluk güçlerinin Tie Fighter araçları hızla ve aynı 'kükreme' sesiyle yaklaştığında seyircinin arzuladığı geri dönüş için ortam hazırlanmış oluyor. Bu haliyle, 'Güç Uyanıyor' aynen bir tarih müzesinin işlevini üstleniyor. Ziyaretçilerinin kişisel hatıralarını aktifleştirmek için etkiselliği (affect) yüksek kayıp eşyaları bir araya getirerek bir sergi açıyor" (Aktaran Balca, 2016).
}

Yıldız Savaşları Güç Uyanıyor Filmi'nin üç retro afiş kampanyası (Şekil 1), 1977 yılında kullanılan film posterinden ilham alınarak tasarlanmıştır. Afişte böylesine basit ve sade detaylar ile ilk filmin posterinde yer alan "A long time ago in a galaxy far, far away (Uzun zaman önce, çok uzak bir galakside)" cümlesinin kullanılması, izleyicide geçmişle bütünleşik bir merak duygusunu körüklemektedir. Geçmişte ortaya çıkan kahramanlar yerine, kimlerin geleceğine dair bir soru işareti bırakan bu afişlerde, nostalji, ilham veren bir unsur olarak da belirmektedir. Retro reklamın geçmişi taklit etmesi, efsaneleşmiş bir marka için özellikle filmin fanatik izleyicisinin merakını cezbettirmektedir. Belki de yapımcılar tarafından filmin ilk günkü heyecanının yeniden yaşatılması hedeflenmiş, eş zamanlı olarak markanın sadık kitlesine nostaljik bir hayal köprüsü çizilmiştir. Gerçeklikten kaçarak üst-gerçeklikte kurulan bir kozmoza davet eder nitelikte oluşturulan bu afişlerdeki mesajlar yoluyla, hayran kitleyi içine alan bir tarzda "Senin galaksin", "Güç seni çağırıyor" ifadelerine yer verilmiştir. Bu aynı zamanda sosyal medyada ve çoğu internet sitesinde dolaşımda olan bu afişlerin genç tüketiciler tarafından yeniden yorumlanması anlamına gelmektedir. Küresel çapta ve kuşaklar üstü bir konumlandırmayla tüketicilerin zihninde yer eden Yıldız Savaşları, nostaljiyi sadece film afişinde değil, dijital oyunlar, oyuncaklar ve markaya ait pek çok ürün yoluyla da yaşatmakta ve nostaljik pazarlama stratejisinin bir gereği olarak verdiği mesajlara, toplumun her kesiminden bireylerinin kayıtsız kalamayacağı varsayılmaktadır. BBC'nin haberine göre, tüm dünyada Yıldız Savaşları serisinin son filminin, 
bir milyar dolar hasılata en hızlı ulaşan film olarak (BBC, 07.01.2016) bir rekor kırması, buna bir kanıt olarak gösterilebilmektedir.

Şekil 1. Walt Disney'in, Yıldız Savaşları Güç Uyanıyor Filmi İçin Hazırladığı Üç Retro Poster (SCRO, Cenk Atlı, 30.11.2015)
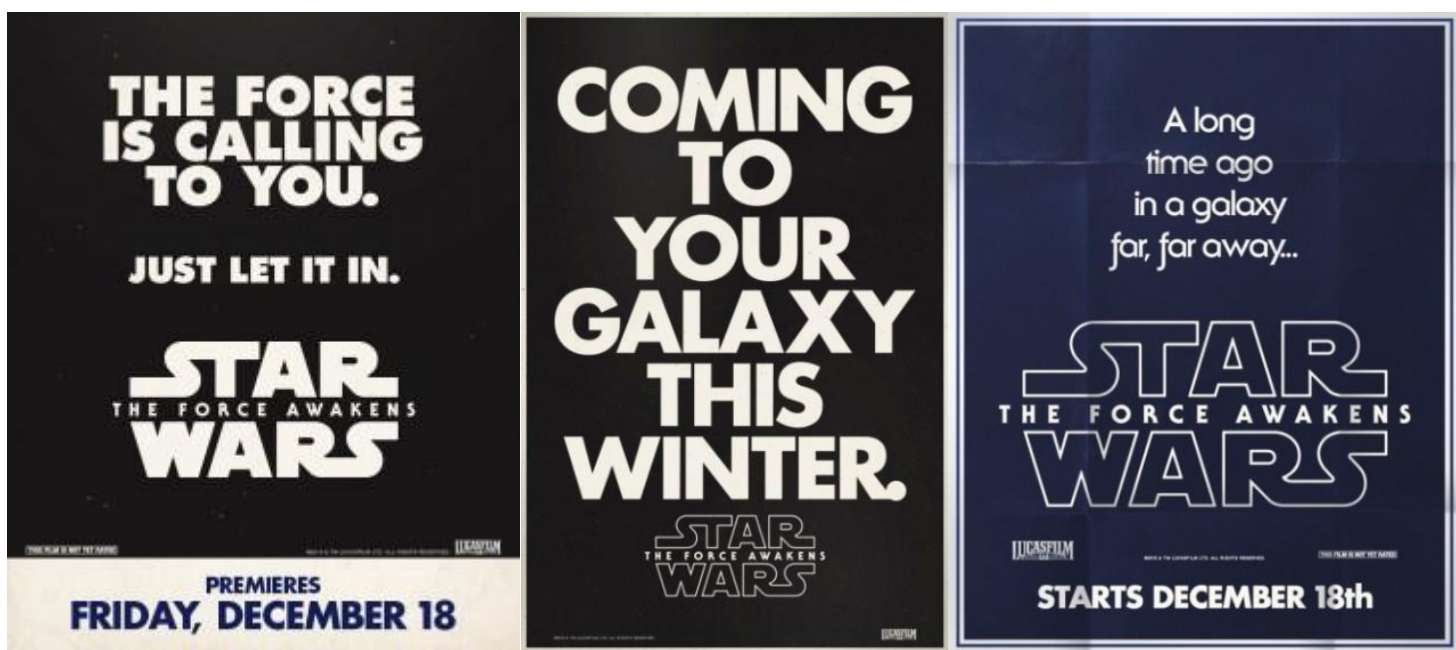

Gerek retro reklamlarda, gerekse nostaljik unsurların kullanıldığı reklamlarda görüldüğü üzere nostalji kavramı, tüketiciyle markayı buluşturan pozitif bir etken olarak belirmektedir. Reklamlarda nostalji kullanımı, özellikle gençlerin ve çocukların sevdiği hamburger ve çikolata gibi gıda ürünlerinin gösterildiği Pino Lezzet Durağı reklamı örneğindeki gibi, markayı rakiplerden ayıran köklü bir etken olabiliyorken, EtiWanted Çikolatası Retro Reklam örneğindeki gibi geçmişin sevilen karakterleri aracılığıyla belleklerde yer alan olumlu hislerin markaya transferi şeklinde de olabilmektedir. Geçmişe ait çağrışımlardan veya geçmiş ürünlerin marka mirasına dayanarak (Ogechukwu, 2013:29) oluşturulan reklamlarda eski şarkı, imaj, slogan ya da sembollerin kullanılması marka kimliğini güçlendirmeye yaramaktadır. Retro reklamlarda kullanılan geçmişle bağı olan herhangi tanıdık bir simge, Yıldız Savaşları Güç Uyanıyor Filmi'nde benzer bir biçimde yer bulan nostaljik yazı karakteri ve nostaljik slogan, markanın müşterisiyle kurduğu duyu temas noktasında, marka mirasına dayanarak, markanın kimliğini sağlamlaştırmaya yardımcı olurken, öte yandan markayı güncel bir platforma da taşımaktadır. Nerdeyse kırk yı önceki duyguların canlandırılmaya çalışıldığı bu yeni film afişinin sosyal medyada paylaşımı, nesilden nesle aktarılan duygulara da aracılık edebilmekte, bu yolla gençler, kişilerarası nostaljinin etkisiyle büyükleri ya da ebeveynleriyle benzer hisleri yaşayabilmektedirler.

\section{Yöntem}

\subsection{Araştırmanın Amacı ve Önemi}

$\mathrm{Bu}$ araştırmanın amacı postmodern bireylerin nostalji eğilimlerini belirlemek ve reklamlarda kullanılan nostalji temasına karşı yaklaşımlarını öğrenmeye çalışmaktadır. Postmodern bireylerin nostalji eğiliminin farklı boyutlarının araştırılması yoluyla nostaljinin satın alma davranışlarıyla ilişkisinin de görünür kılınacağı varsayılmaktadır. İçinde bulunduğumuz bilişim çağında şimdinin yarattığı olumsuz duygulardan dolayı insanların süreklilik, aidiyet, güvenlik gibi arayışlarında nostalji kavramı öne çıkmakta, bu durum nostaljiyi daha genç yaşlarla ilişkilendirmeye olanak tanımaktadır. Nostaljiyi genç bireylerle ilişkilendiren araştırmaların eksikliğinden yola çıkılarak gerçekleştirilen araştırmada, elde edilen bulguların ulusal ve uluslararası literatüre katkıda bulunacağı düşünülmektedir. 


\section{2. Örneklem}

Araştırmada yöntem olarak nicel bir veri toplama tekniği olan anket tekniğinden yararlanılmıştır. Araştırmanın $Y$ Kuşağı olarak tanımlanan evreni içinden, örneklemin belirlenmesinde kohort yöntemi kullanılmıştır. Mason ve Wolfinger tarafından, kohort bir grubu tanımlayan değerler şu şekilde açıklanmaktadır:

"Bir kohort aynı anda sisteme giren bireylerden oluşur. Aynı kohort içinde yer alan bireyler ortak deneyimleri nedeniyle diğer kohortlardan ayrışır. Kohort analizi kohortlar arası farklılıkları araştırmayı amaçlar" (2001:1).

Bu çalışmada 1980 ile 1985 yılları arasında doğanlardan oluşan beş yıllık bir kohort kesitiyle benzer özellikler gösterdiği düşünülen kişilerin nostaljiye bakış açısı analiz edilmiştir. Beş yıllık bir kesiti kapsayan örneklemin seçiminde 1980 yılının baz alınmasındaki gerekçe, postmodern kavramının toplumsal yaşamda yaygın olarak bu yıldan itibaren kullanılmış olmasıdır. Araştırma evreni olarak 1980-2001 yılı arası doğanlar olarak tanımlanan Y Kuşağı içinde sadece beş yıllık bir örneklem grubunun tercih edilmesinin nedeni, kuşak eleştirilerine dayanmaktadır. Kuşak farklıklarını bilimsel temelden ziyade popülist bulan eleştirilere göre kuşakların farklı tutum ve değerlere sahip olduğu iddiasının anekdot ve gözlemlere dayalı olması (Macky vd., 2008; Sullivan vd., 2009; Aktaran Gürbüz, 2015:40) ve araştırmalarda tutarlı sonuçlar elde edilememiş olması (Benson \& Brown, 2011; Aktaran Gürbüz, 2015:40) gibi nedenlerden ötürü beş yıllık bir kesit tercih edilmiştir. Ayrıca kuşaklar arasındaki sınırların ülkelere göre farklılıkları açıklayamamasından dolayı; örneğin 1980 yılından itibaren doğanlardan oluşan (dijital doğanlar olarak da anılan) Y Kuşağının, Türkiye'de bilgisayar, internet ve mobil teknolojilerinin daha geç gelişiminden dolayı, bazı araştırmalarda, başlangıcının 1991 yılı baz alınarak tanımlanması (Bayhan, 2014:15) gibi sorunlardan ötürü, örneklem seçiminde kuşak araştırmaları yerine kohort yönteminden yararlanılmıştır.

Araştırma kapsamında kolayda örneklem yöntemi ile seçilen 142 katılımcıya, 27 Mart-17 Nisan 2016 tarihleri arasında anket uygulanmıştır. Örneklem kapsamına alınan 1980-1985 arası doğumlular dijital yerliler olarak da tanımlanan bir gruptur. Araştırmaya katılan cevaplayıcıların demografik verilerine bakıldığında; katılımcıların tamamının 1980-1985 yılları arasında doğduğu; 94 kadın (\%66,2), 48 erkek $(\% 33,8)$ katılımcı olduğu görülmektedir. Katılımcıların 2'si ilköğretim $(\% 1,4), 56$ 'sı lise $(\% 39,4), 51^{\prime}$ i üniversite $(\% 35,9)$ ve $33^{\prime}$ ü yüksek lisans $(\% 23,2)$ mezunudur.

\subsection{Araştırma Modeli ve Hipotezler}

Bu çalışmada kullanılan araştırma modeli aşağıda gösterilmiştir (Şekil 2).

\section{Şekil 2. Araştırma Modeli}

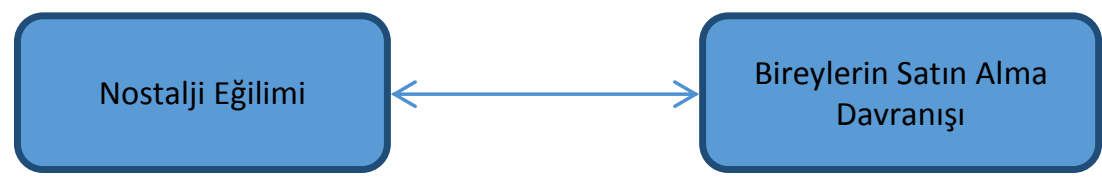

H1: Bireylerin nostalji eğilimi ile bireylerin satın alma davranışları arasında anlamlı bir ilişki vardır.

\section{4. Ölçüm Araçları ve Uygulama}

Araştırmada kullanılan soru formu katılımcılara daha kolay ulaşabilmek amacıyla internet ortamında dağıtılmıştır. Anket formunda ilk bölümde araştırmaya katılanlara yöneltilen yaş, cinsiyet, öğrenim durumu gibi demografik sorular yer almaktadır. Ayrıca hangi mecrayı bireylerin reklam için daha etkili bulduğu ve hangi mecranın bilgi edinme için kullanıldığına dair iki soru daha sorulmuştur. Anketin ikinci bölümünde nostalji eğilimini ölçmek amacıyla Holak vd. (2006) tarafından geliştirilen ölçek kullanılmıştır. ifadeler Gökaliler ve Aslan (2015) tarafından yapılan çalışmada Türkçeye çevrilmiştir. Anketin son bölümünde ise 
nostaljik içerikli reklamların tüketici satın alma davranışını etkileme düzeyi, Toksarı ve Senir (2015) tarafından da Türkçe olarak kullanılan ölçek aracılığı ile ölçülmüştür. Cevaplar 5'li Likert ölçeğinde (1: Kesinlikle Katılmıyorum, 2: Katılmıyorum, 3: Kararsızım, 4: Katılıyorum, 5: Kesinlikle Katılıyorum) hazırlanmıştır. Anket verileri SPSS 20 programında analiz edilmiş, korelasyon ve regresyon analizleri yapılmıştır.

\section{Bulgular}

\subsection{Betimleyici Analizler}

Reklamların hangi mecrada yapılırsa daha etkileyici olduğu sorusuna verilen cevaplar değerlendirildiğinde 67 katılımcının televizyon (\%47,2), 55 katılımcının internet (\%38,7), 12 katılımcının Açıkhava (\%8,5), 5 katılımcının doğrudan postalama $(\% 3,5), 2$ katılımcının gazete $(\% 1,4)$ ve 1 katılımcının radyoyu en etkileyici bulduğu görülmektedir.

Satın alma aşamasından önce, mal ve hizmetlerle ilgili bilgi edinmede en çok kullanılan bilgi kaynağının hangisi olduğu konusunda 93 katılımcı $(\% 65,5)$ internet yanıtını vermiştir. İkinci en sık verilen yanıt ise aile ve yakın çevre $(20$ kişi $\% 14,1)$ olmuştur. 16 katılımcı arkadaş grubu $(\% 11,3)$ yanıtını verirken, 8 katılımcı satıcı ve satış yerlerini $(\% 5,6), 5$ katılımcı ise reklamları $(\% 3,5)$ bilgilendirici bulduğunu ifade etmiştir.

Veri setinin normal dağılıma sahip olup olmadığını tespit etmek için örnek sayısı büyük (örnek sayısı $>50$ ) olduğundan Kolmogorov-Smirnov testi yapılmış ve $p$ değerlerinin 0.05 değerinin üzerinde olduğu görülmüştür.

\subsection{Faktör Analizi}

Hem nostalji eğilimi, hem nostaljik içerikli reklamların tüketici satın alma davranışını etkileme düzeyi testlerindeki ifadelerin hangi faktörler altında toplandığını görmek amacıyla, iki test de ayrı ayrı faktör analizine tabi tutulmuştur. Nostalji eğilimi modelinin faktör analizi sonucunda otuz bir ifadenin dokuz faktör altında toplandığı görülmüştür. Yapılan güvenirlik analizi sonucunda ise üç faktörün alfa değerlerinin, geçerli minimum sınııın (\%60) altında kaldığı görüldüğünden analiz dışında bırakıımıştır. Geriye kalan yirmi üç ifadenin altı faktör altında toplanarak toplam varyansın \%60,418'ini açıkladığı görülmüştür. Güvenirlik analizine tabi tutulan altı faktörün güvenirliklerinin kabul edilen sınırların üzerinde olduğu tespit edilmiştir. Elde edilen faktörler kişisel nostalji (faktör 1), kişilerarası ve canlandırılmış nostalji (faktör 2), geçmişe aidiyet (faktör 3), ilişkisel nostalji (faktör 4), bugünden memnuniyetsizlik (faktör 5), geri dönüş (faktör 6) olarak adlandırılmıştır. Faktör analizine ilişkin sonuçlar, faktörlerin güvenirlik sonuçları ve ortalama değerleri Tablo 2'de sunulmaktadır. Ölçeğin faktör analizine uygunluğu için uygulanan KMO testi (0.830) sağlıklı bir faktör analizine devam edilebileceğini ve Bartlett Testi sonucu da (Sig:0,000; $p<0.05)$ değişkenler arası yüksek korelasyon olduğunu göstermektedir. 
Tablo 2. Nostalji Eğilimi Testine İlişkin Faktör Analizi Sonuçları

\begin{tabular}{|c|c|c|}
\hline & Faktör Katkısı & Cronbach Alpha \\
\hline Faktör 1- Kişisel nostalji & 29,941 & 0.764 \\
\hline Sıkılıkla çocukluğumdan anları düşünürüm & 0,586 & \\
\hline Eski güzel günleri özlüyorum & 0,598 & \\
\hline Üzgün olduğumda neşelenmek için geçmişi düşünürüm & 0,562 & \\
\hline Sıklıkla geçmişte yaşadığım hisleri tekrar yaşamayı isterim & 0,743 & \\
\hline Bazen zamanı 20 yıl öncesine döndürebilmek isterdim & 0,737 & \\
\hline Faktör 2- Kişilerarası ve canlandırılmış nostalji & 8,032 & 0.692 \\
\hline Çektiğim fotoğraflara bakmayı severim & 0,499 & \\
\hline Aile büyüklerimin tecrübelerini dinlemeyi sevmem & 0,746 & \\
\hline Sıklıkla ailemin kendi hayatlarına dair anlattığı hikâyeleri düşünürüm & 0,690 & \\
\hline $\begin{array}{l}\text { Bazen ülkemin tarihinde önemli olayların yaşandığı dönemlerde } \\
\text { yaşamak isterdim }\end{array}$ & 0,529 & \\
\hline Faktör 3- Geçmişe aidiyet & 6,388 & 0.759 \\
\hline Ailemle veya arkadaşlarımla eski günleri anmayı severim. & 0,584 & \\
\hline Geçmişimle ilgili mutlu hatıralarım mutsuz olanlardan daha fazla & 0,742 & \\
\hline Kendi yaş grubumdan kişilerle kendimi özdeşleştiririm & 0,438 & \\
\hline Geçmişi yad ettiğimde tatmin olurum & 0.553 & \\
\hline $\begin{array}{l}\text { Geçmişte ziyaret ettiğim veya yaşadığım yerleri hatırlamak } \\
\text { memnuniyet verir }\end{array}$ & 0.653 & \\
\hline $\begin{array}{l}\text { Geçmişin bir parçasını yaşatan veya canlandıran bir gruba ait olmayı } \\
\text { isterim }\end{array}$ & 0.483 & \\
\hline Faktör 4- İlişkisel nostalji & 6,002 & 0,643 \\
\hline Geçmişten kişiler ve mekânlar benim için özellikle anlamlıdır. & & \\
\hline Eski okul arkadaşlarımı çok sık düşünmem* & & \\
\hline Eski okul arkadaşları toplantılarına katılmayı severim & & \\
\hline Faktör 5- Bugünden memnuniyetsizlik & 5,370 & 0,530 \\
\hline Geçmişte yaşadıklarımı düşünüp daldığım anlar olur & 0.585 & \\
\hline Bazen başka bir zaman ve mekanda yaşamayı isterdim & 0.729 & \\
\hline Bugün yaşadıklarımı geçmişte yaşadıklarımla değerlendirmem* & 0.633 & \\
\hline Faktör 6- Geri dönüş & 4,684 & 0,649 \\
\hline Eski TV ve radyo programlarını yenilerden daha çok beğenirim & 0.721 & \\
\hline Gençliğimin filmleri daha iyiydi & 0.824 & \\
\hline \multicolumn{3}{|l|}{ Kaiser-Meyer-Olkin Value: .830 df:253 } \\
\hline Bartlett Significance:.000 Chi square: 1174,707 & & \\
\hline
\end{tabular}

* Ters ifade

Nostaljik içerikli reklamların tüketici satın alma davranışını etkileme düzeyi ile ilgili yedi ifade faktör analizine tabi tutulduğunda, yedi ifadenin iki faktör altında toplandığı ve toplam varyansın \%70,357'sini açıkladığı görülmektedir. Güvenirlik analizine tabi tutulan iki faktörün güvenirliklerinin oldukça yüksek olup, elde edilen faktörler duyguları tetikleme (faktör 1) ve tüketime yöneltme (faktör 2), olarak isimlendirilmiştir. Nostalji içerikli reklamların satın alma alışkanlıklarına etkisi konusunda sorulan ifadelere ilişkin faktör analizi sonuçları Tablo 3'de sunulmaktadır. 
Tablo 3. Nostalji i̇çerikli Reklamların Satın Alma Davranışına Etkisine i̇lişkin Faktör Analizi Sonuçları

\begin{tabular}{|l|c|}
\hline & Faktör Katkısı \\
\hline Faktör 1- Duyguları tetikleme & Varyans Değeri \%54,438 \\
Nostalji içerikli reklamlar bana geçmişteki bir olayı hatırlatır & 0,841 \\
$\begin{array}{l}\text { Nostalji içerikli reklamlar geçmişteki olayları hatırlatması sebebiyle } \\
\text { bende hem üzüntü hissi yaşatır hem de aynı zamanda beni mutlu } \\
\text { kılar }\end{array}$ & 0,806 \\
$\begin{array}{l}\text { Nostalji içerikli reklamlar geçmişe dair bende herhangi bir duygu } \\
\text { uyandırmaz* }\end{array}$ & 0,869 \\
$\begin{array}{l}\text { Nostalji içerikli reklamlar geçmişte yaşadığım anıları tekrardan } \\
\text { yaşamama yardımcı olur }\end{array}$ & 0,855 \\
$\begin{array}{l}\text { Faktör 2- Tüketime yöneltme } \\
\text { Tanıtım ve reklamlarında nostalji içerikli mesajlara vurgu yapan } \\
\text { firmaları tercih ederim } \\
\text { Milli ve dini bayramlara vurgu yapan nostalji içerikli reklamlar beni } \\
\text { mutlu eder } \\
\text { Ürünlerin ambalaj ve logolarının nostalji içerikli olması benim ürüne } \\
\text { yönelmemde etkilidir }\end{array}$ & Varyans Değeri \%15,919 \\
\hline $\begin{array}{l}\text { Kaiser-Meyer-Olkin Value: .835 df:21 } \\
\text { Bartlett Significance:.000 Chi square: } \mathbf{4 6 5 , 4 4 2}\end{array}$ & 0,372 \\
\hline
\end{tabular}

Ayrıca değişkenlerin faktör boyutlarına ait ortalama değerler aşağıda belirtilmiştir. Bu tabloya bakıldığında katılımcıların ortalama değer etrafında yargıda bulundukları görülmektedir.

Tablo 4. Ortalama ve Standart Sapma Değerleri

\begin{tabular}{|lcc|}
\hline Faktör & Ortalama & Standart Sapma \\
\hline Kişisel Nostalji & 2.5592 &, 728 \\
Kişilerarası Nostalji & 2.2958 & .702 \\
Geçmişe Aidiyet & 2.2289 & .588 \\
ilişkisel Nostalji & 2.4329 & .691 \\
Bugünden Memnuniyetsizlik & 2,270 &, 631 \\
Geri dönüş & 2,510 &, 870 \\
\hline
\end{tabular}

\subsection{Korelasyon Analizi}

Araştırmanın temel değişkenleri arasındaki ilişkiyi genel olarak incelemek amacıyla korelasyon analizine baş vurulmuştur. Nostalji eğilimi değişkenleri (F1,F2,F3,F4,F5,F6) ile nostalji içerikli reklamların tüketici davranışına etkisi değişkenleri (R1 ve R2) arasında korelasyon analizine ilişkin sonuçlar Tablo 5'te gösterilmektedir. Analize göre tüm faktörler arasında zayıf sayılsa da anlamlı ilişkiler tespit edilmiştir. Ancak en yüksek anlamlı ilişki nostalji eğilimi ölçeğinin ikinci faktörü (F2; kişilerarası ve canlandırılmış nostalji) ile nostalji içerikli reklamların tüketicideki etkisini ölçen iki faktör (duyguları tetikleme arasında ve tüketime yöneltme) arasında bulunmuştur ( $r=0,594 ; r=0561 p=0.00)$. Geri dönüş olarak isimlendirilen son faktör ile tüketicinin duygularının etkilenmesini içeren faktör arasında da yine anlamlı ilişki bulunmuştur ( $r=0.416$, $\mathrm{p}=0.00)$. 
Tablo 5. Korelasyon Tablosu

\begin{tabular}{|c|c|c|c|c|c|c|c|c|}
\hline & \multirow{2}{*}{$\begin{array}{l}\text { Kişisel } \\
\text { Nostalji }\end{array}$} & \multirow{2}{*}{$\begin{array}{l}\text { Duyguları } \\
\text { Tetikleme }\end{array}$} & \multirow{2}{*}{$\begin{array}{l}\text { Kişilerarası } \\
\text { Nostalji }\end{array}$} & \multirow{2}{*}{$\begin{array}{l}\text { Geçmişe } \\
\text { Aidiyet }\end{array}$} & \multirow{2}{*}{$\begin{array}{l}\text { ilişskisel } \\
\text { Nostalji }\end{array}$} & \multirow{2}{*}{$\begin{array}{l}\text { Bugünden } \\
\text { Mem. }\end{array}$} & \multirow{2}{*}{$\begin{array}{l}\text { Geri } \\
\text { Dönüş }\end{array}$} & \multirow{2}{*}{$\begin{array}{l}\text { Tüketime } \\
\text { Yönelme }\end{array}$} \\
\hline & & & & & & & & \\
\hline Kişisel Nostalji & 1 & & & & & & & \\
\hline Duyguları tetikleme &, $373^{* *}$ & 1 & & & & & & \\
\hline Kişilerarası Nostalji & ,544 &, $594^{* *}$ & 1 & & & & & \\
\hline Geçmişe Aidiyet &, $565^{* *}$ &, $428^{* *}$ &, $496^{* *}$ & 1 & & & & \\
\hline İlişkisel Nostalji &, $333 * *$ &, $300 * *$ & $428^{* *}$ &, $480 * *$ & * 1 & & & \\
\hline Bugünden Memnuniy & etsizlik,296** & ,342** &, $302 * *$ &, $311^{* *}$ & * ,339** & * 1 & & \\
\hline Geri dönüş & ,308** & ,416** & ,410** &, $373^{* *}$ & * , 279** & $*, 227 * *$ & 1 & \\
\hline Tüketime Yöneltme &, $296 * *$ &, $516 * *$ &, $561 * *$ &, $401 * *$ & $*, 309 * *$ & * ,216** &, $328 * *$ & 1 \\
\hline
\end{tabular}

Hipotezi test etmek için yapılan korelasyon analizi neticesinde nostalji eğiliminin bütün faktörleri ile nostalji içerikli reklamların satın alma davranışı arasındaki ilişkiye dair tüm faktörler arasında pozitif ve anlamlı bir ilişki çıkmıştır.

\subsection{Regresyon Analizi}

Nostaljiye eğilim modelindeki ifadelerin faktör analizine tabi tutulmasıyla elde edilen altı boyutun nostalji unsurları içeren reklamlara yönelik tüketici davranışını üzerindeki açıklayıcılıklarını test etmek üzere regresyon analizi kullanıımıştır. Regresyon analizinde, bağımsız değişkenler arasında çoklu bağlantı olmadığı görülmüştür. Regresyon analizi öncesinde ayrıca bağımsız değişkenler arası çoklu bağlantının (multicollinearity) varlığının testi için Doğrusal Regresyon uygulanmış ve Varyans Büyütme Faktörü (VIF) ve Tolerans (TOL) Değerleri incelenmiş, değişkenler arası çoklu bağlantının bulunmadığı tespit edilmiştir.

Nostalji eğilimi boyutları ve nostalji unsurlarının duyguları tetiklemeye yönelik etkisi arasında yapılan regresyon analizi sonucuna göre, $F$ testinin 16.335 ve modelin anlamlı $(p=, 000)$ olduğu görülmüştür (Tablo 6). Modelin açıklayıcılığı ise \% 42 'tir. Nostalji eğilimi boyutları arasında ikinci faktör (kişilerarası ve canlandırılmış nostalji), dördüncü faktör (bugünden memnuniyetsizlik) ve altıncı faktöre (geri dönüş) ait anlamlıık düzeyleri $0.05^{\prime}$ den küçük olduğundan modelde yer almaktadır.

Tablo 6. Nostalji Eğilimi Boyutları ve Nostaljik Unsurların Duyguları Tetikleme Etkisi Arasında Regresyon Analizi

\begin{tabular}{|c|c|c|c|}
\hline \multicolumn{4}{|c|}{ Bağımlı Değişken: Duyguları tetikleme } \\
\hline Bağımsız Değişkenler & Beta & t değeri & p değeri \\
\hline Kişisel nostalji &,- 028 & -.325 & ,746 \\
\hline Kişilerarası nostalji & ,446 & 5,187 & ,000 \\
\hline Geçmişe aidiyet & 134 & 1.513 & 133 \\
\hline İlişkisel nostalji & -.045 &,- 569 & ,570 \\
\hline \multicolumn{4}{|l|}{ Bugünden } \\
\hline Memnuniyetsizlik & .150 & 2.086 & .039 \\
\hline Geri dönüş & .171 & 2.312 & .022 \\
\hline
\end{tabular}


Nostalji eğilimi boyutları ve nostalji unsuru içeren reklamların tüketime yöneltmesi arasında uygulanan regresyon analizi sonuçları Tablo 7'de özetlenmektedir.

Tablo 7. Nostalji Eğilimi Boyutları ve Nostaljik Unsurların Tüketime Yöneltmesi Arasında Regresyon Analizi

\begin{tabular}{lccc} 
Bağımlı Değişken: Tüketime Yöneltme & \\
Bağımsız Değişkenler & Beta & $\mathbf{t}$ değeri & $\mathbf{p}$ değeri \\
\hline Kişisel nostalji &,- 103 & $-1,127$ &, 262 \\
Kişilerarası nostalji &, $\mathbf{4 8 0}$ & $\mathbf{5 , 2 6 4}$ &, 000 \\
Geçmişe aidiyet &, 170 & 1,819 &, 071 \\
ilişkisel nostalji &, 024 &, 289 &, 773 \\
Bugünden & & & \\
Memnuniyetsizlik &, 021 &, 269 &, 788 \\
Geri dönüş &, 088 & 1,119 &, 265 \\
\hline
\end{tabular}

R: 0,590; R2: 0.348; adjusted R2: 0.319; F değeri $=12.025 ; p$ değeri $=.000$

Analizler sonucu düzeltilmiş araştırma modeli Şekil 3'de gösterilmektedir.

Şekil 3. Regresyon Analizi Sonucu Yenilenen Araştırma Modeli

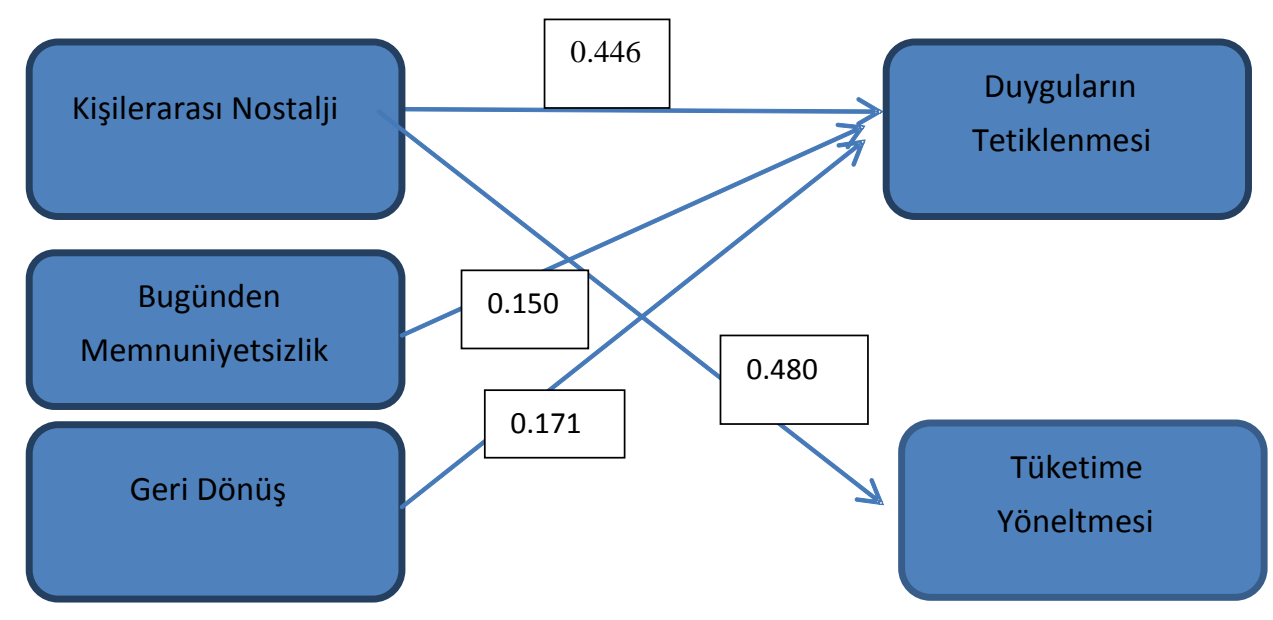

Bu analizler tartışma ve sonuç bölümünde ilgili yazın ile ilişkilendirilerek açıklanmaktadır.

\section{Tartışma ve Sonuç}

Her sektörde artan rekabet ve postmodern yaşamın getirdiği öncelikler, marka yöneticilerinin tüketiciye ulaşma, iletişime geçme ve ikna etme süreçlerinde yenilikler yapmalarını zorunlu hale getirmiştir. Günden güne artan pazarlama araştırmalarının merkezinde günümüz tüketicisini daha hızlı ve derinden etkileyecek unsurlar bulma arayışı yatmaktadır. Ogechukwu'nun (2013) belirttiği gibi geçmişe ait çağrışımlara ya da geçmiş ürünlerin marka mirasına dayanan reklamlarda kullanılan logo, sembol ya da sloganlar marka kimliğini güçlendiren unsurlar olarak sayılmaktadır. Postmodern pazarlamanın bir unsuru olarak görülen nostalji, geçmişe ait sıcak duyguların yeniden canlandırılması yoluyla bir yandan marka 
imajını olumlarken, diğer yandan Belk'in (1990) ifadesiyle, belirsizlik ve güvensizlik duygularının yaşandığı modern toplumlarda güvenli bir liman olarak algılanmaktadır.

Nostaljik içerikli reklamların postmodern bireylerle ilişkisinin araştırıldığı bu çalışmada, öncelikli olarak katıımcıların hangi reklam araçlarını etkileyici buldukları incelenmiştir. Her ne kadar katılımcılar satın alma aşamasından önce bilgi alma yöntemi olarak interneti tercih ettiklerini söyleseler de, konu reklam olduğunda kitlesel iletişim araçlarından televizyonun diğer araçlardan daha etkileyici olduğu tespit edilmiştir. Satın alma aşamasından önce bilgi kaynağı olarak öne çıkan interneti, ikinci sırada aile ve yakın çevre, üçüncü sıradaysa arkadaşlar izlemektedir.

"Nostalji Eğilimi Testine İlişkin Faktör Analizi Sonuçları" bulgularına göre, katılımcıların doğrudan deneyime dayanan "kişisel nostalji", "ilişkisel nostalji" , "kişilerarası ve canlandırılmış nostalji" ve "geri dönüş" olarak adlandırılan kavramlar öne çıkmıştır. Taşkaya'nın (2013) reklamlarda nostaljik unsurların işlenmesine ilişkin çalışmasında köklülük, aidiyet veya kimlik gibi vurgulardan bahsetmesinden hareketle, mevcut çalışmada da katılımcıların geçmişin (tarihin) bir parçasına ait olma isteğinin altında kendisini daha değerli kılma arzusu yatmaktadır. Bu durum örneklem grubunun dolaylı kolektif deneyime dayanan "kişilerarası ve canlandırımış nostalji" kategorisini ifade ettiği şeklinde yorumlanabilir. Katılımcıların postmodern bireyler olarak nispeten genç yaşta olmalarına rağmen, doğrudan olduğu kadar, dolaylı geçmiş deneyimlere de önem vermesi, aile, yakın çevre, tarih ve kültürel olguların referans olarak alındığını göstermektedir. Bu da nostalji kategorisi içinde yer alan farklı türde nostaljik eğilimlerin, sadece ileri yaşlarda beliren bir eğilim türü olmadığını, yaşı daha genç bireylerde de görülebildiği anlamına gelmektedir. Bu noktada Hemetsberger, Kittinger-Rosanelli ve Mueller'in (2012) araştırma bulgularında da gerek çocukluk, erken deneyim ya da alışkanlıklarından, gerekse ebeveynlerin deneyimlerinden oluşan nostaljinin, henüz 30'lu yaşlarını süren bireyler tarafından benimsendiği dile getirilmiştir.

Çalışmanın ikinci bölümünde nostalji içerikli reklamların tüketiciler üzerinde, duyguları tetikleme ve tüketime yöneltme olarak iki boyutlu etkisi olduğu belirlenmiştir. Araştırmanın bulgularına göre, duyguları tetikleme boyutu çok daha yüksek oranda nostalji unsurunun tüketici davranışı üzerindeki etkisini açıklamaktadır. Bir diğer ifadeyle geçmiş tecrübelerin özlemle hatırlanması nostalji içerikli reklamlara karşı örneklem grubunun ilgi duyduğunu göstermektedir.

Gökaliler \& Arslan (2015) da çalışmalarında, retro markalara yönelik duygusal yakınlık ile retro markaların tüketici zihninde olumlu hatıralar yansıtması arasında ilişkiye dikkat çekerek, duygusal bağ kurma sürecinde hatıraların öneminin altını çizmiştir. Mevcut araştırmada da görüldüğü üzere nostalji içeren reklamların, postmodern markalama stratejisi bağlamında, tüketiciyi satışa yönlendirme amacıyla değil, duygulara hitap ederek oluşturulması önerilmektedir.

Katılımcıların eski TV programlarını, dizilerini ve filmlerini yenilere tercih etmesi, Star Wars'un yönetmeni Lucas tarafından nostaljinin niçin önemsendiğini de açıklamaktadır. Bu filmler aracılığıyla izleyicinin kişisel hafızası aktif hale getirilerek, geçmişle bugün arasındaki bağın kurulması sağlanmakta ve bu şekilde geri dönüş ortamı yaratılmaktadır. Tanıdık ve iyi hislerin beslendiği kahramanlar, hikayeler, nesneler, sloganlar ya da simgeler aracılığıyla geçmişe ait güvenli duygular yeniden canlandırılmakta, bu yolla marka sadakati de kuvvetlendirilmektedir.

Araştırmanın temel kısıtlarına bakıldığında, bunlardan birisi verilerin sınırlı sayıda katılımcıdan toplanmış olmasıdır. İleride bu konuyu çalışacak araştırmacıların farklı yaş gruplarından karşılaştırmalı bir analiz yapmalarının faydalı olacağı öngörülmektedir. Ayrıca yapılacak olan araştırmaların deneysel yöntemleri içermesi; yani farklı nostaljik temaları içeren reklamların kullanıldığı araştırmaların yapılacak olması, sonuçlara da katkı sağlayacaktır.

Sonuç olarak değerlendirildiğinde araştırmaya katılan örneklem grubunun günümüzde birçok markanın hedef kitlesi içinde yer aldığı bilinmektedir. Genel kanının aksine nostalji içerikli reklamların sadece ileri yaştaki tüketicilere üzerinde değil, daha genç yaşlardaki tüketici grupları üzerinde de etkili olduğu söylenebilir. Bu bağlamda postmodern markalama stratejisi uygulayan firmaların, nostaljiye ağılık verirken hedef kitlelerinin nostalji anlayışını iyi analiz etmeleri gerekliliği arz etmektedir. Ayrıca postmodern 
markalamanın en önemli unsuru olan "otantiklik" kavramının yanında nostalji kavramı da öne çıkmakta, nostaljinin anlam arayışında olan tüketicilere bir çözüm alternatifi sunmaya çalışması, pazarlama dünyasında her geçen gün daha fazla konuşulacağı varsayımını desteklemektedir.

\section{Kaynaklar}

Alwin, D. F. (2002). Generations X, Y and Z: Are They Changing America. American Sociological Association, Contexts, 42(1), 42- 51.

Balca, A. (2016). Nostaljik Seyrin Kayıp Nesnesi: Yıldız Savaşları VII / Güç Uyanıyor (Star Wars VII / The Force Awakens). 06.01.2016.

http://davetsizmisafir.org/2016/01/06/nostaljik-seyrin-kayip-nesnesi-yildiz-savaslari-vii-guc-uyaniyor-star-wars-viithe-force-awakens/, Erişim Tarihi: 22.04.2016.

Baudrillard, J. ([1982] 2011). Simülakrlar ve Simülasyon. Çev. Oğuz Adanır. Ankara: Doğu Batı Yayınları.

Bayhan, V. (2014). The Sociological Context Millennium or (Y) Youth. Journal of Youth Research, Volume 2., Issue 3. 826.

BBC, Star Wars'tan Gişe Hasılatı 07.01 .2016 . http://www.bbc.com/turkce/haberler/2016/01/160107_star_wars_kuzey_amerika), Erişim Tarihi: 28. 04. 2016.

Belk, R. W. (1990). The Role of Possessions in Constructing and Maintaining a Sense of Past. In NA-Advances in Consumer Research, Volume 17, pp. 669-676. http://www.acrwebsite.org/volumes/7083/volumes/v17/NA-17i, Erişim Tarihi: 10. 03. 2016.

Benson, J., \& Brown, M. (2011). Generations At Work: Are There Differences and Do They Matter. The International Journal of Human Resource Management, 22(9), 1843-1865.

Brown, S., Kozinets, R., \& Sherry J. (2003). Teaching Old Brands New Tricks: Retro Branding and the Revival of Brand Meaning. Journal of Marketing. Vol. 97 (July), 19-33.

Dağtaş, B. (2003). Reklamı Okumak. Ankara: Ütopya Yayınevi.

Davis, F. (1979). Yearning for Yesterday: A Sociology of Nostalgia. New York: The Free Press.

Dyer, G. (2010). Iletişim Olarak Reklamcılık. Çev. M. Nurdan Öncel Taşkıran. İstanbul: Beta.

Estevez, S. M. (2009). Is Nostalgia Becoming Digital? Ecuadorian Diaspora in The Age of Global Capitalism. In Social Identities: Journal for the Study of Race, Nation and Culture. Taylor \& Francis Online. Volume 15, Issue 3. Erişim: http://www.tandfonline.com/doi/pdf/10.1080/13504630902899366, Erişim Tarihi: 15. 03. 2016.

Franzen, G. (2002). Reklamın Marka Değerine Etkisi. Çev. Fevzi Yalım. İstanbul: MediaCat.

Giep, F. (2005). Reklamın Marka Değerine Etkisi. Çev. Fezvi Yalım. İstanbul: MediaCat.

Gökaliler, E., \& Aslan, Z. (2015). Geçmişle Bağ Kuran Bir Pazarlama Yaklaşımı: Retro Pazarlama Perspektifinden Tüketicilerin Marka Kimliği ve Marka İmajına Bakış Açıları Üzerine Bir Araştırma. Global Media Journal TR $\begin{array}{lllll}\text { Edition, } & 6 & \text { (11) 240-260. }\end{array}$ http://globalmediajournaltr.yeditepe.edu.tr/makaleler/GMJ_11._sayi_guz_2015/pdf/13.pdf, Erişim Tarihi: 17. 03. 2016.

Gürbüz, S. (2015). Kuşak Farklıııları: Mit mi, Gerçek mi?. İş ve Insan Dergisi. (Nisan-April) Volume-Issue: 2 (1), 39-57.

Hemetsberger, A., Kittinger-Rosanelli, C., \& Mueller, B. (2012). Grandma's Fridge is Cool: The Meanning of Retro Brands for Young Custumers. Advences in Consumer Research, Vol. 38, 242-248.

Holak, S. L., Havlena, W. J., \& Matveev, A. V. (2006). Exploring Nostalgia in Russia: Testing the Index of NostalgiaProness. European Advences in Consumer Research, Vol. 7, 195-200.

Holbrook, M. P. (1993). Nostalgia and Consumption Preferences: Some Emerging Patterns of Consumer Tastes. Journal of Consumer Research, 20/2, 245-256. http://www.jstor.org/stable/2489272?seq=1\#page_scan_tab_contents, Erişim Tarihi: 19. 03. 2016.

Holbrook, M. P., \& Schindler, R. (1989). Some Expoloraty Findings on the Development of Musical Tastes. Journal of Consumer Research. 16/1, 119-124.

Kellner, D. (1992). Popular, Culture and Construction of Postmodern Identities. Modernity and Identity. (Ed.) S. Lash-J Friedman. Cambridge: Blackwell, pp.141-177. 
Kotler, P. (2015). A'dan Z'ye Pazarlama. Çev. Aslı K. Bakkal. 2.Bs. İstanbul: MediaCat.

Lindstrom, M. (2007). Duyular ve Marka. Çev. Ümit Şensoy. İstanbul: Optimist Yayınları.

Löwy, M., \& Sayre, R. (2016). İsyan ve Melankoli: Moderniteye Karşı Romantizm. Çev. Işık Ergülen. İstanbul: Alfa.

Macky, K., Gardner, D., \& Forsyth, S. (2008). Generational Differences at Work: Introduction and Overview. Journal of Managerial Psychology, 23 (8), 857-861.

Mason, W. M., \& Wolfinger, N. H. (2001). Cohort Analiysis. (Ed.) Neil J. Smelser and Paul B. Baltes International Encyclopedia of Social and Behavioral Sciences. Amsterdam: Elsevier Science. Erişim: http://papers.ccpr.ucla.edu/papers/PWP-CCPR-2001-005/PWP-CCPR-2001-005.pdf, Erişim Tarihi: 25. 03. 2016.

Odabaşı, Y. (2004). Postmodern Pazarlama. İstanbul: MediaCat.

Ogechukwu, D. A. (2013). Retro-Marketing: The Art of Bringing Back to Life/Revatilising an Old Brand (Product) - The Nigerian Experience. Universal Journal of Management and Social Sciences, Volume 3, Number 3 (March), 1648.

Rosenau, P. M. (1998). Postmodernizm ve Toplumbilimleri. Çev. Tuncay Birkan. Ankara: Bilim ve Sanat Yayınları.

Rutherford, P. (2000). Yeni ikonalar: Televizyonda Reklam Sanatı. Çev. Mustafa K. Gerçekler. İstanbul: Yapı Kredi Yayınları.

SCRO, Cenk Atlı, "Star Wars Çılgınlığı Bu Retro Posterlerle Yeni Bir Boyut Kazanıyor”, 30.11.2015. http://www.scroll.com.tr/star-wars-cilginligi-retro-posterlerle-yeni-bir-boyut-kazaniyor/, Erişim Tarihi: 28. 04. 2016.

Sedikides, C., Wildschut T., Arndt, J., \& Routledge, C. (2008). Nostalgia: Past, Present, and Future. Association for Psychological Science, Volume 17, Number 5, pp. 304-307. http://www.southampton.ac.uk/ crsi/Sedikides\%20Wildschut\%20Arndt\%20\%20Routledge\%202008\%20CDir.p df, Erişim Tarihi: 11.03.2016.

Stern, B. B. (1992). Nostalgia in Advertising Text: Romancing the Past. Advances in Consumer Research, Volume 19, 388-389.

Sullivan, S. E., Forret, M. L., Carraher, S. M., \& Mainiero, L. A. (2009). Using the Kaleidoscope Career Model to Examine Generational Differences in Work Attitudes. Career Development International, 14 (2-3), 284-302.

Taşkaya, M. (2013). Reklamda Nostaljik Unsurlar: Kimlik Vaadi ve Anlamın Tüketimi. ETHOS: Felsefe ve Toplumsal Bilimlerde Diyaloglar, 6/1 (Ocak), 1-37.

Toksarı, M., \& Senir, G. (2015). Menşe Ülke Etkisinin Satın Alma Kararı Üzerindeki Etkisi. Journal of International Social Research, 8(40).

Turner, B. S. (2002). Oryantalizm, Postmodernizm ve Globalizm. Çev. İbrahim Kapaklıkaya. İstanbul: Anka Yayınları.

Ulusoy, E. (2005). Faydacı Tüketim ve Hedonik Tüketim Yapılarının Reklamlara Yansıması: İki Volkswagen Reklamı. İçinde Reklamların Içinde/N. (Ed.) Mete Çamdereli. Konya: Tablet Yayınları.

Üskül-Engin, Z. Ö. (2005). Yüzyılımızın Postmodern Bireyi ve Baudrillard'ın Birey Anlayışı. İstanbul Üniversitesi Hukuk Fakültesi, IUHFM C. LXIII, S. 1-2, 139-167.

Yeygel, S. (2006). Postmodern Toplumsal Yapının Pazarlamaya Getirdiği Yeni Boyut: Topluluk Pazarlaması (Tribal Marketing). BILIG, (Yaz) Sayı 38, s. 197-228. http://www.acarindex.com/dosyalar/makale/acarindex1423873336.pdf, Erişim Tarihi: 01. 03. 2016.

Zaltman, G. (2003). Tüketici Nasıl Düşünür?. Çev. A. Semih Koç. İstanbul: Marka Yayınları. 